\title{
SuDS and amphibians - are constructed wetlands really benefitting nature and people?
}

\author{
D. O’Brien ${ }^{1}$, J. Hall ${ }^{1}$, A. Miró2 ${ }^{2}$ M. Rae ${ }^{3}$ \& R. Jehle 4 \\ ${ }^{1}$ Highland Biological Recording Group, c/o 7 Woodside of Culloden, Inverness IV2 5BP \\ ${ }^{2}$ Centre for Advanced Studies of Blanes, Spanish Research Council (CEAB-CSIC), Accésa la Cala St. Francesc, 14, \\ Blanes17300, Girona, Catalonia, Spain \\ ${ }^{3}$ Highland Council, Glenurquhart Road, Inverness IV3 5NX \\ ${ }^{4}$ University of Salford, School of Environment and Life Sciences, Manchester M5 4WT
}

E-mail: David.OBrien@nature.scot

\begin{abstract}
While urbanisation is a major threat to global biodiversity, it also brings opportunities for some species. Sustainable Drainage Systems (SuDS) have been installed in all Scottish cities to reduce flood and pollution risk and they can also offer new habitats for wildlife. We studied SuDS in Inverness and the Scottish Central Belt to assess their value as amphibian breeding sites, habitats, and as places where urban people can experience nature. The nine-year study revealed that many SuDS were of similar ecological quality to wider countryside ponds but that the quality of ponds is not equitably distributed between neighbourhoods inhabited by different socio-economic classes. However, the findings suggest ways to improve the design and management of SuDS for people and nature, making access to high quality ponds available to all social groups.
\end{abstract}

\section{INTRODUCTION}

Urban expansion is a major threat to biodiversity (Beninde et al., 2015). Expanding cities take away land from biodiversity, perturb "natural processes" such as flooding and nutrient cycling, and fragment habitats. Urban citizens are less likely to experience nature and the health and well-being effects it provides. The alienation of young people from nature has been termed "nature-deficit disorder" (Louv, 2005), and has been linked to physiological, emotional and social problems. However, when sympathetically managed, urban green (parks and gardens) and blue spaces (coast, ponds, lochs, canals and rivers) can provide valuable wildlife habitats (Hill et al., 2016; Aronson et al., 2017) especially when the surrounding countryside has been degraded by intensive agriculture (Deutschewitz et al., 2003; Colding \& Folke, 2009).

Cities can provide novel habitats for species. For example, two bryophytes, common liverwort (Marchantia polymorpha) and silver moss (Bryum argentium), thrive in pavement cracks (Atherton et al., 2010), cliff-nesting birds such as peregrines (Falco peregrinus) nest on buildings, and scavenging species like foxes (Vulpes vulpes) and gulls (Larus spp.) exploit human rubbish. Some groups such as pollinators and passerine birds appear to be very successful in urban gardens.

However, not all species have benefitted from urbanisation. Amphibians are amongst the most threatened taxa. These threats come from climate change, introduced species, pathogens spread by humans, over-exploitation, chemical pollution, habitat loss, as well as urbanisation. Even so, some species, like common frog (Rana temporaria) have been quick to colonise urban gardens, often with the help of home-owners (Beebee \& Griffiths, 2000). There is evidence that urban common frogs and common toads (Bufo bufo) have lower genetic diversity than their rural counterparts, perhaps because of population isolation (Hitchings \& Beebee, 1997, 1998).

An increasing form of green and blue space in cities is SuDS. Whilst their primary purpose is water management, we postulated that SuDS ponds might also bring benefits to biodiversity. This could be through their role as breeding sites (Jones \& Fermor, 2001), habitats for a range of species (Woods-Ballard et al., 2015), and connecting otherwise isolated populations to form metapopulations as part of a habitat network. Furthermore they could bring urban-dwelling humans into contact with nature, with consequent health and well-being benefits (Hill et al., 2016; O'Brien et al., 2015; Parris, 2016; WoodsBallard et al., 2015). Amphibians were chosen as a model taxon as they are relatively easy to find and survey, disperse over a comparatively small area, and are sensitive to pollution. The study areas include Inverness, one of the fastest growing settlements in Europe since 2000, and the Scottish Central Belt, an area with a long history of development for housing and industry. 


\section{METHODS}

We carried out amphibian breeding surveys initially in 12 ponds in Inverness during 2010-2013 (O'Brien, 2015), and then in all 40 Inverness SuDS during 2014-2017 (Miró et al., 2018) following the National Amphibian and Reptile Recording Scheme protocol (ARG-UK, 2013). We also carried out freshwater invertebrate surveys in the $40 \mathrm{SuDS}$ following the OPAL protocol (Davies et al., 2011) in 2014. In 2017 we extended the project to 38 SuDS ponds in Central Scotland, surveying for invertebrates and amphibians (Rae et al., 2019).

For all 78 ponds, we carried out detailed habitat assessments following the protocols developed by one of the authors (AM), initially for use in the Pyrenees but modified for use in Scotland (Miró et al., 2017), including assessing ten designable or manageable characteristics previously linked to SuDS ecological quality (O'Brien, 2015; WoodsBallard et al., 2015).

To assess equality of access to these ponds, we used data from the most recent Scottish census in 2011 (National Records of Scotland, 2016) to assess the comparative population economic wealth surrounding SuDS, and considered the relationship between these data and the findings on the ecological quality of neighbouring SuDS. We restricted this part of the study to Inverness to remove the influence of other socio-economic impacts such as demographic history. Detailed methods can be found in O'Brien (2015) and Miró et al. (2018).

\section{RESULTS}

\section{Do amphibians breed in SuDS ponds?}

Over the nine-year study, we found that common local native amphibians, common frog, common toad and palmate newt (Lissotriton helveticus) bred successfully in at least 21 out of 23 SuDS ponds. When we extended the study to the Scottish Central Belt, we found evidence of breeding by two additional native newt species, the smooth newt ( $L$. vulgaris) and the European protected great crested newt (Triturus cristatus), as well as the introduced Alpine newt (Ichthyosaura alpestris). Thus all of Scotland's native and introduced amphibians, with the exception of the natterjack toad (Bufo/Epidalea calamita), were shown to breed in SuDS.

\section{Do SuDS offer good habitats?}

Five biotic and abiotic ecosystem components were highly correlated and accurately described SuDS ecological quality: amphibian richness, macroinvertebrate richness, macrophyte richness, terrestrial habitat richness and urbanisation (Miró et al., 2018). Chemical analysis ( $\mathrm{pH}$, ammonia, nitrate, nitrite, phosphate and chloride ions) showed that none of the ponds contained pollutants at levels known to have adverse effects on amphibians. Nutrient levels in Inverness SuDS are lower than those found in a previously published sample of lowland British ponds: six of the 12 SuDS ponds had $\mathrm{NO}_{3}$ concentrations $<0.5 \mathrm{mg} \mathrm{l}^{-1} \mathrm{~N}$ and phosphate $<0.05 \mathrm{mg} \mathrm{l}^{-1} \mathrm{P}$ (i.e. below levels which would normally be considered eutrophic) (O'Brien, 2015). This was reflected by the diversity of invertebrate taxa found, which included groups that are characteristic of unpolluted water such as Odonata, Ephemeroptera and Trichoptera (Rae et al., 2019). Ecological quality of many ponds was comparable with wider countryside ponds, though some showed a legacy of nearby industrial contamination (e.g. Glenrothes, Fife).

\section{Can SuDS ponds bring urban-dwellers into contact with nature?}

While public events held as part of the project showed that SuDS can bring local people into contact with nature, the wide variation in ecological quality means this potential benefit is not equitably available to all those who live near SuDS (Miró et al., 2018). Furthermore, these findings suggest that those from the poorest social backgrounds are more likely to live near SuDS of poor ecological quality (Miró et al., 2018).

\section{DISCUSSION}

These findings support the hypothesis that SuDS ponds might bring benefits to biodiversity and people: as breeding sites; by connecting otherwise isolated populations to form metapopulations as part of a habitat network; and by bringing urbandwellers into contact with nature, with consequent health and well-being benefits (Fig. 1).

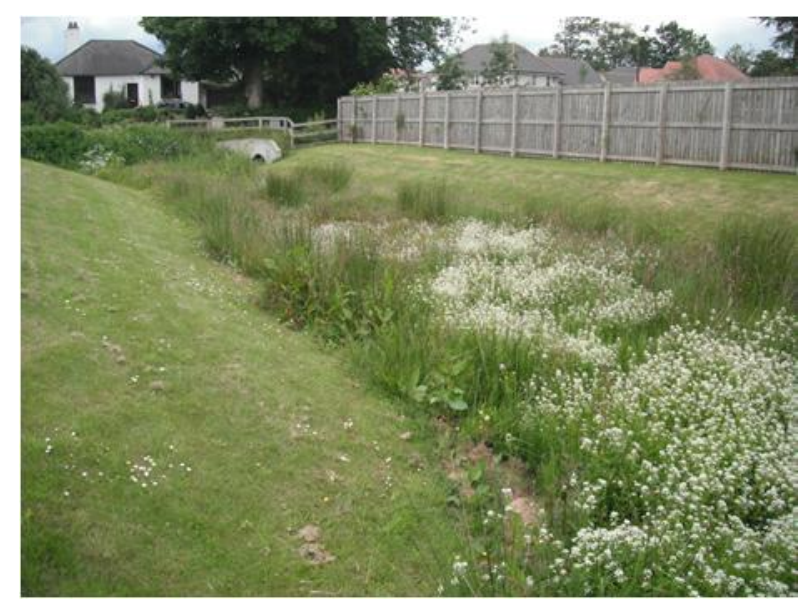

Fig. 1. SuDS swale with high macrophyte diversity adjacent to a green path, with cycling and pedestrian access at the back left of the image. Note the lack of barriers, other than where the path is immediately next to the SuDS. This site is used by local families for recreation and holds large breeding populations of common frogs (Rana temporaria) and palmate newts (Lissotriton helveticus). (Photo: D. O’Brien)

The frequency with which we found metamorphosed amphibians at SuDS suggests that they are most likely acting as source, rather than sink populations, though we have not undertaken the detailed population studies required to confirm this. 
As part of the project, we carried out a public event at one of the ponds, which attracted over 100 people (Rae et al., 2019). Most of these were local families with children, suggesting that when made aware of the value of SuDS, people are genuinely enthusiastic. For children, the opportunity to grow up in contact with nature has also been linked to improved mental health and educational outcomes (Bingley \& Milligan, 2004). However, we found that these benefits are not equitably distributed: poorer neighbourhoods have SuDS of lower ecological quality, though this can be improved by design and management (Miró et al., 2018). Ponds offer greater diversity of wildlife than other types of SuDS, such as swales and detention basins.

\section{How can we use these findings?}

In both a fast-growing city and in long-established towns and cities, SuDS are generating multiple benefits for amphibians and humans, whilst also serving an important role in the drainage system. These could be further increased through improved design and management (Fig. 2). We are now extending these findings to some of the most deprived urban areas of Europe, through links with the Green Infrastructure Strategic Intervention managed by Scottish Natural Heritage and part of the 2014-2020 European Regional Development Fund (ERDF) programme.

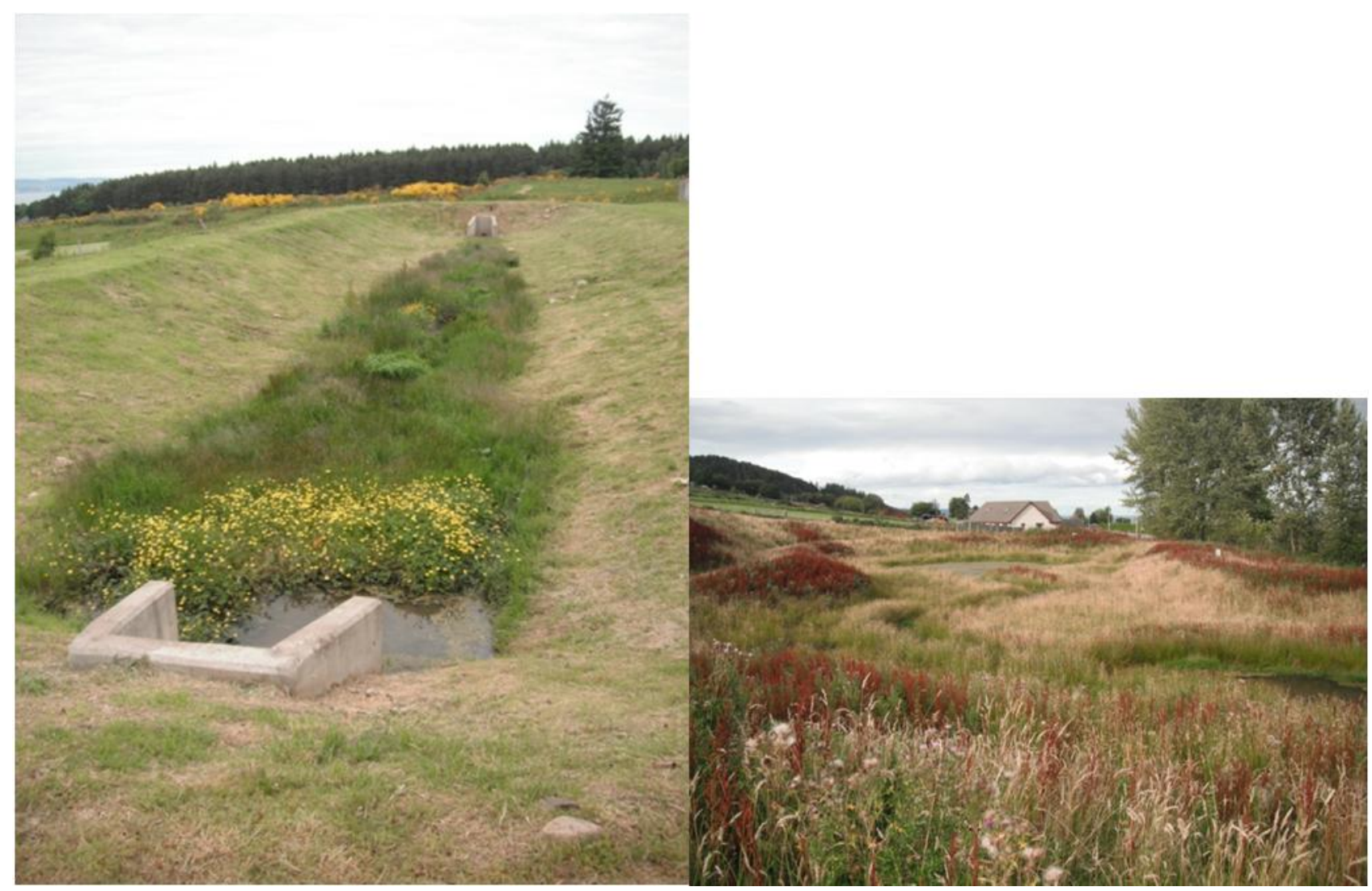

Fig. 2. Influence of the mowing regime on macrophytes at SuDS. Note the large area of cover plants in the right image compared with the left image where mowing has occurred. Such habitat supports grasshopper warblers (Locustella naevia) and water voles (Arvicola amphibius), as well as foraging habitat for common frogs (Rana temporaria), common toads (Bufo bufo) and palmate newts (Lissotriton helveticus). (Photos: D. O’Brien)

\section{REFERENCES}

ARG-UK. (2013). NARRS Amphibian Survey Protocols (v. 2013). Amphibian and Reptile Groups of the United Kingdom.

Aronson, M.F.J., Lepczyk, C.A., Evans, K.L., Goddard, M.A., Lerman, S.B., MacIvor, J.S. et al. (2017). Biodiversity in the city: key challenges for urban green space management. Frontiers in Ecology and the Environment 15, 189-196.

Atherton, I., Bosanquet, S. \& Lawley, M. (2010). Mosses and Liverworts of Britain and Ireland: $A$ Field Guide. British Bryological Society, Plymouth.
Beebee, T.J.C. \& Griffiths, R.A. (2000). Amphibians and Reptiles: a Natural History of the British Herpetofauna. HarperCollins, London.

Beninde, J., Veith, M. \& Hochkirch, A. (2015). Biodiversity in cities needs space: a meta-analysis of factors determining intra-urban biodiversity variation. Ecology Letters 18, 581-592.

Bingley, A. \& Milligan, C. (2004). Climbing Trees and Building Dens: Mental Health and Well-being in Young Adults and the Long-term Effects of Childhood Play Experience. Research Report. Institute for Health Research. Lancaster University, Lancaster. 
Colding, J. \& Folke, C. (2009). The role of golf courses in biodiversity conservation and ecosystem management. Ecosystems 12, 191-206.

Davies, L., Bell, J.N.B., Bone, J., Hill, M., Head, L. Howard, C. et al. (2011). Open Air Laboratories (OPAL): A community-driven research programme. Environmental Pollution 159, 22032210.

Deutschewitz, K., Lausch, A., Kuhn, I. \& Klotz, S. (2003). Native and alien plant species richness in relation to spatial heterogeneity on a regional scale in Germany. Global Ecology and Biogeography 12, 299-311.

Hill, M.J., Biggs, J., Thornhill, I., Briers, R.A., Gledhill, D.G., White, J.C. et al. (2016). Urban ponds as an aquatic biodiversity resource in modified landscapes. Global Change Biology 23, 986-999.

Hitchings, S.P. \& Beebee, T.J.C. (1997). Genetic substructuring as a result of barriers to gene flow in urban Rana temporaria (common frog) populations: implications for biodiversity conservation. Heredity 79, 117-127.

Hitchings, S.P. \& Beebee, T.J.C. (1998). Loss of genetic diversity and fitness in common toad (Bufo bufo) populations isolated by inimical habitat. Journal of Evolutionary Biology 11, 269-283.

Jones, M. \& Fermor, P. (2001). Sustainable Drainage Systems - maximising the opportunity to meet biodiversity targets. In: Proceedings First National Conference on Sustainable Drainage. Coventry University, 18-19 June 2001.

Louv, R. (2005). Last Child in the Woods: Saving our Children from Nature-deficit Disorder. Algonquin Books, Chapel Hill, North Carolina, U.S.A.

Miró, A., O'Brien, D., Hall, J. \& Jehle, R. (2017). Habitat requirements and conservation needs of peripheral populations: the case of the great crested newt (Triturus cristatus) in the Scottish Highlands. Hydrobiologia 792, 169-181.

Miró, A., Hall, J.E., Brae, M. \& O'Brien, C.D. (2018). Links between ecological and human wealth in drainage ponds in a fast-expanding city, and proposals for design and management. Landscape and Urban Planning 180, 93-102.

National Records of Scotland (2016). 2011 Scotland's Census. Scottish Government.

http://www.scotlandscensus.gov.uk/ . (Accessed 1st November 2016.)

O'Brien, C.D. (2015). Sustainable drainage system (SuDS) ponds in Inverness, UK and the favourable conservation status of amphibians. Urban Ecosystems 18, 321-331.

Parris, K.M. (Editor) (2016). Ecology of Urban Environments. Wiley-Blackwell, Chichester, West Sussex.

Rae, M., Miró, A., Hall, J.E., O'Brien, K. \& O'Brien, D. (2019). Evaluating the validity of a simple citizen science index for assessing the ecological status of urban drainage ponds. Ecological Indicators 98, pp.1-8.
Woods-Ballard, B., Wilson, S., Udale-Clarke, H., Illman, S., Scott, T., Ashley, R. et al. (2015). The SUDS Manual. CIRIA report C753. CIRIA, London. 